\title{
GAS8 wt Allele
}

National Cancer Institute

\section{Source}

National Cancer Institute. GAS8 wt Allele. NCI Thesaurus. Code C54263.

Human GAS8 wild-type allele is located in the vicinity of $16 q 24.3$ and is approximately 25 $\mathrm{kb}$ in length. This allele, which encodes growth-arrest-specific protein 8 , plays a role in cell cycle regulation and growth arrest. 